\title{
THE HWOCR PROGRAM
}

DR. CHARLES L. STORRS

Director, HWOCR Program Office

Atomics International - Combustion Engineering

Paper Presented at

the C.N.A. Conference

Winnipeg, Canada

May 30, 31 and June 1, 1966

\section{CANADIAN NUCLEAR ASSOCIATION}




\section{DISCLAIMER}

This report was prepared as an account of work sponsored by an agency of the United States Government. Neither the United States Government nor any agency Thereof, nor any of their employees, makes any warranty, express or implied, or assumes any legal liability or responsibility for the accuracy, completeness, or usefulness of any information, apparatus, product, or process disclosed, or represents that its use would not infringe privately owned rights. Reference herein to any specific commercial product, process, or service by trade name, trademark, manufacturer, or otherwise does not necessarily constitute or imply its endorsement, recommendation, or favoring by the United States Government or any agency thereof. The views and opinions of authors expressed herein do not necessarily state or reflect those of the United States Government or any agency thereof. 


\section{DISCLAIMER}

Portions of this document may be illegible in electronic image products. Images are produced from the best available original document. 
THE HWOCR PROGRAM

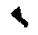

H. C. $\$ 1.00 ; \mathrm{MN} .50$

by

Charles L. Storrs, Director

HWOCR Program Office

\section{LEG A L NOT I CE}

This report was prepared as an account of Government sponsored work. Neither the Unlted States, nor the Commission, nor any person acting on behalf of the Commission:

A Makes any warranty or representation, expressed or implied, with respect to the accuracy, completeness, or usefulness of the information contained in this report, or that the use of any information, apparatus, method, or process disclosed in this report may not infringe privately owned rights; or

B. Assumes any liabtlities with respect to the use of, or for damages resulting from the se of any information, apparatus, method, or process disclosed in this report.

As used in the above, "person acting on behalf of the Commission" includes any employ us or extractor, to the extent tha ployee or controces disseminates, or provides access to, any information pursuant to his employment or contract disseminates, or provides access to, any information pursuant
with the Commission, or his employment with such contractor.

Presented at

the

\section{Canadian Nuclear Association Meeting}

Winnipeg, Canada

May 30 - June 1, 1966

ATOMICS INTERNATIONAL-COMBUSTION ENGINEERING A Jolnt Venture for Heavy Water Organic Cooled Reactors

HWOCR Program Office

Canoga Park, California 


\section{THE HWOCR PROGRAM *}

The motivations for developing the Heavy Water, Organic Cooled Reactor are the conservation of uranium resources through efficient fuel utilization, the reduction of power generation costs, and the ability to scale up the design to the very large sizes being considered for desalination. The excellent neutron economy inherent in heavy water reactors results in a significant increase in the amount of power which can be generated from a given amount of ore. When the uranium required for inventory in a rapidly expanding nuclear economy is taken into account, this increase will be a factor of 1.5 to 2 in comparison to light water reactors. Such an improvement in dynamic fuel utilization will postpone the depletion of low cost uranium ore reserves, providing more time for discovery of new ore resources or for the development of economic fast breeder reactors.

The second benefit from the good neutron economy is the potential achievement of low fuel cycle costs and low energy generation costs. We estimate fuel cycle costs of about $8 \dot{\xi}$ per million BTU and energy generation costs of less than $3.5 \mathrm{mills} / \mathrm{kwh}$ for our reference plant, using interest rates appropriate for an invester-owned utility. The good neutron economy also leads to flexibility in the use of different fuels, including natural uranium and thorium, without the necessity for redesign of basic reactor components. Because the HWOCR is relatively insensitive to rising fuel prices, and because it can be adapted to a variety of fuels, it will be useful under most circumstances which can be foreseen.

The use of organic coolant is also important to achieving the objectives of the program. It permits the heavy water to be operated at low temperatures and pressures, thus minimizing inventory and losses of this expensive material. The low vapor pressure of the organic coolant permits use of thin walled pressure tubes which reduces parasitic neutron absorption. The primary coolant loop can also be designed for low pressures using relatively inexpensive steels, while obtaining the thermodynamic efficiency of a superheat steam cycle. The low level of radioactivity normally present in the coolant permits normal maintenance of the primary loop while the plant is in operation.

* Work presented in this paper was performed under USAEC Contract $\mathrm{AT}(38-1)-430$. 
The pressure tube design contributes in several important ways. It permits on-line refueling, which greatly reduces the excess reactivity and the resultant neutron losses to the control system. Moreover, this refueling system provides great flexibility in fuel management, and increases the availability of the plant. Finally, the pressure tube approach permits design of very large reactors using the same components demonstrated on smaller ones.

Our work on the HWOCR at Atomics International-Combustion Engineering is organized around the design of three general plant sizes sharing many common features. The reference plant, which is our primary objective, is a $1000 \mathrm{Mwe}$ plant utilizing design parameters which will be tested in a few years as a result of the development program which is in progress. Before constructing this plant, however, we propose to build a demonstration plant using design parameters based either on existing technology or that which is predictable for the very near future. This plant is required to demonstrate the essential features of the concept, including the estimates of high fuel utilization, low energy generation costs, and high availability. It is also expected to qualify the actual components of the reference plant where practicable. Our third design goal is a very large plant for the desalination of water as well as the generation of electrical power. Plant sizes up to $10,000 \mathrm{Mwt}$ are under study. Because all three systems use many of the same components, most of the design and development work, and my remarks here today, are equally applicable to all three.

The figure shows the general arrangement of the reactor components. This same arrangement would be used for all the plant designs. The fuel and organic coolant are contained in vertical pressure tubes. These tubes are about 4 inches in diameter and 20 feet long. They are made of dispersion hardened aluminum, or SAP, 0.12 inches in thickness. About $6 \mathrm{Mwt}$ are produced per tube. These pressure tubes penetrate the calandria tank containing the heavy water moderator. The calandria tubes are of zirconium, 0.06 inches thick, and are insulated from the pressure tubes by a 0.3 inch gas gap. The reactor is regulated with horizontal control rods which penetrate the sides of the reactor. The actuators are outside the shield and are accessible during operation.

The design incorporates on-power refueling using a pair of refueling machines located above and below the reactor. The refueling scheme is to move the fuel through the reactor in opposite directions in alternate pressure tubes. This procedure surrounds each nearly spent fuel element with four fresh fuel elements recently inserted. Coolant flow is in the same direction as fuel movement, so that the fresh fuel is cooled by the lowest temperature 


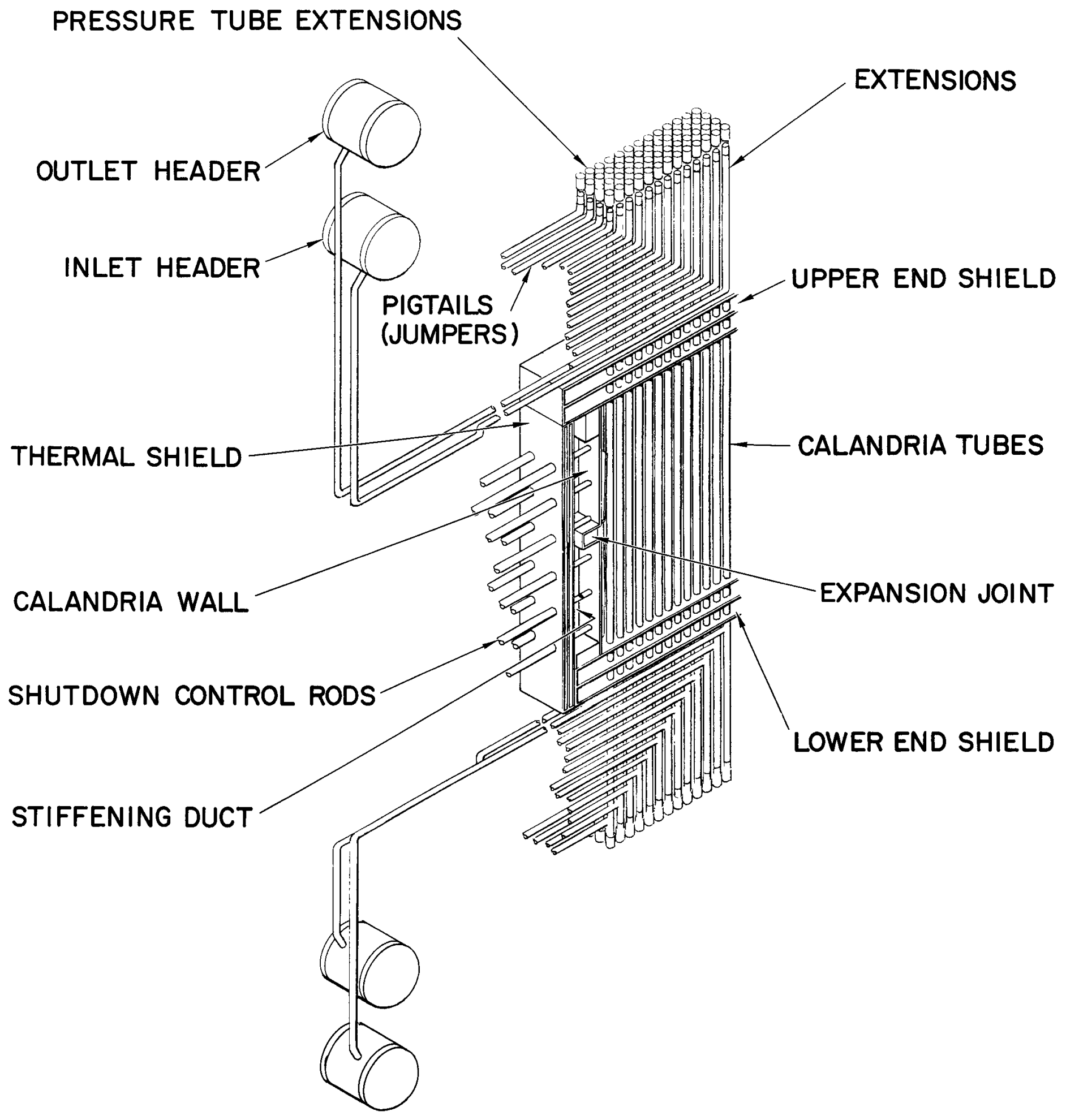

Figure 1. HWOCR Pressure Tube Module 
coolant. At equilibrium conditions all the fresh fuel is identical in enrichment; radial power flattening is achieved by allowing the central fuel elements to go to a higher burnup. The modular construction of pressure tubes and control devices shown in the illustration will permit us to build reactors of different slzes, including the very large ones, without redesigning these components. Since this arrangement will be proven on the demonstration plant, progress to subsequent plants should be rapid.

A modular approach has also been taken for the coolant loops. Three loops will be used for the $1000 \mathrm{Mwe}$ reference plant. Each loop, consisting of a pump, steam generator, superheater, reheater, and the associated valves and piping, is designed to handle about $1000 \mathrm{Mwt}$. The pumps have a capacity of $83,000 \mathrm{gpm}$, and are located at the reactor outlet, in contrast to common practice, in order to minimize the pressure in the reactor. The steam generated in the three coolant loops goes to a single 1000 Mwe turbine-generator. The steam cycle conditions are $900 \mathrm{psi}, 725^{\circ} \mathrm{F}$, with reheat to $725^{\circ} \mathrm{F}$. For the demonstration plant either one, or preferably two, coolant loops would be designed for use such that the development of reliable large organic components would not have to be repeated for subsequent applications.

Our present thinking on containment arrangement places the reactor and its emergency cooling systems inside the containment building, with the main coolant pumps and steam generators located outside. Isolation valves in tandem are placed where the coolant lines penetrate the building. These will close rapidly and automatically in case of an accident. By placing the steam generators outside the reactor building, the necessity of containing the large volume of steam resulting from a massive steam generator failure is avoided, as are the numerous penetrations of the structure for the steam lines. The result is an effective safeguard system at a moderate cost.

This reactor design utilizes several critical materials which are the subject of corresponding key development areas. The fuel is uranium carbide clad in SAP. We have selected carbide because its high density and high thermal conductivity permit us to design a reactor with very high power density. We are able to use the carbide because it is compatible with the organic coolant. We are using SAP for cladding because of its low neutron absorption; because it is compatible with both fuel and coolant; because of its high thermal conductivity; and because of its strength at elevated temperature. Our design will take into account the disadvantage assoclated with its lack of ductility. 
In-pile fuel testing is being carried out at the NRU and the WR-1. A fuel string, consisting of both SAP-clad carbide and $\mathrm{Zr}$-clad oxide fuel elements was installed in the U-3 loop at NRU last July. (The Zr-clad oxide is our alternate fuel deslgn.) The Table shows a comparison of this test with the conditions for initial operation of the demonstration plant. At the end of March the local peak burnup in the carbide fuel had reached over $9000 \mathrm{Mwd} /$ MTU, about half the burnup desired for the initial operation of the demonstration plant.

The first fuel assembly for the WR-1 tests is scheduled for insertion the first week of April, and the second will be shipped in early May.

The pressure tubes use the same dispersion hardened aluminum as the fuel cladding and for the same reasons. A supply of this material suffictent for the next two years of development work has been ordered. Extrusions of 4 inch tubing have been made successfully. Once the extrusion parameters had been adjusted, seven successful extrusions over 24 feet long were made in seven tries.

The transition joints between the SAP pressure tubes and the steel extensions will be made either by hot pressing or by rolling. The hot pressed joints, which are our reference design, provide a metallurgical bond and are consequently expected to be leak tight. The rolled jolnts promise economic advantages provided a solution can be found for the leakage problem.

An out-of-pile testing program on SAP pressure tubes and transition joints is underway at Combustion Engineering, Windsor, Connecticut. The first test of a full-size SAP tube started in mid-March. A five-channel pressure tube test rig is scheduled to start testing in July.

The organic coolant which has been chosen is Santowax OM ${ }^{* *}$ with $10 \%$ high boiler. OM has been selected in preference to OMP, the Piqua coolant, because its melting point is below the operating temperature of the moderator. This will avold freezing of coolant between the pressure tube and the calandria tube in the event of a leak. The initial filling of the core and startup after a prolonged shutdown will be simplified with $O M$ since the moderator can be used to preheat the reactor. The advantage of OM over HB40*, used in WR-1, is that its high auto-ignition temperature provides a considerable safety margin at our operating temperature of $750^{\circ} \mathrm{F}$.

* Monsanto Company trademark. 
TABLE I.

COMPARISON OF U-305 IRRADIATION EXPERIMENT WITH HWOCR

DEMONSTRATION PLANT FUEL DESIGN

Fuel Assembly Description

Fuel System

Fuel Geometry

Fuel Diameter, in.

Initial Radial Gas Gap, in.

Carbon Content, \%

$\sigma$

U-235 Enrichment, \%

\section{Operating Characteristics}

Coolant Material

Coolant Velocity, ft/sec

Coolant Temperature, ${ }^{\circ} \mathrm{F}$

Cladding Hot Spot

Temperature, ${ }^{\circ} \mathrm{F}$

Maximum Fuel

Temperature, ${ }^{\circ} \mathrm{F}$

Maximum Linear Heat

Rate, kw/ft

Maximum Heat Flux, $\mathrm{Btu} / \mathrm{hr}-\mathrm{ft}^{2}$

Maximum Burnup,

Mwd/MTU

$\frac{\mathrm{U}-305 \text { Experiment }}{\mathrm{UO}_{2}} \underline{\mathrm{UC}}$

$\mathrm{Zr}-4-\operatorname{clad} \mathrm{UO}_{2}$

SAP-clad UC

18 Rod Bundle

18 Rod Bundle

0.522 OD - 0.184 ID

0.499

0.0030

0.0025

- -

$4.82-5.3$

1.12 and 1.52

1.5

Santowax OM $+10-20 \% \mathrm{HB}$

30

$575-650$

860

850

2000

22. 7

326,000

$9000(3 / 11 / 66)$
HWOCR Demonstration Plant

SAP-clad UC

37 Rod Bundle

0.471 and 0.272

0.0035

Nominal 5

1.3

Santowax OM $+10 \% \mathrm{HB}$ 30

$565-694$

775

1760

17.3

240,000

19,300 
In designing for the use of organic coolant, it is necessary to take into account the possibility of the formation of a film on the heat transfer surfaces which would degrade thermodynamic performance. Operation of OMRE, Piqua and various loop experiments indicate that this can be avoided, or in any event controlled, by careful attention to coolant purity and composition. Because the mechanisms are not fully understood, we are planning an extended series of experiments on film formation using a linear accelerator as a radiation source. These experiments will help unravel the basic processes.

As a more empirical approach, we are hoping for continued use of the U-3 loop, at the conclusion of the current test, to study the effects of coolant chemistry upon heat transfer in a fairly realistic reactor environment. The existing alternate fuel strings will be used for these tests. During most of the current U-3 test operation since last July, film formation has been negligible. The sixteen days or so when rapid film formation was indicated colncided with abnormalities in the purity of the coolant. The U-3 experiments together with those using the linear accelerator, will form the basis of a systematic engineering approach to understand film formation more fully.

The second problem presented by the use of organic coolant is principally an economic one: its decomposition under radiation and heat. We plan to use a hydrocracker to recover a large fraction of the high boller resulting from decomposition. The principle of the hydrocracker has been demonstrated on a laboratory scale. We are planning to test a small scale model in connection with an in-pile organic loop. Later, the AEC plans to add a pilot plant hydrocracker to the Piqua organic cooled and moderated reactor. This test will give us the necessary engineering experience to design the hydrocracker for our demonstration plant.

In designing the HWOCR demonstration plant we are applying an availability analysis technique adapted from the aerospace business. By availability I refer to the fraction of design power which the plant is actually able to deliver, on a time-averaged basis. Our overall objective for the plant is $90 \%$ availability, including scheduled maintenance. The purposes of carrying out this analysis at this early stage are to identify critical development areas, to determine the extent of testing which will be required, to guide the design in the direction of reliability and maintainability, to measure the growth of predicted avallability as the development and design progress, and thereby to assure achlevement of high availability when the plant is built.

The procedure which we are using has the following steps.

First, to develop a mathematical model incorporating the precise definition of availability in terms of the rellability of the parts, the length of time required for maintenance, and the effect of failure on plant output. 
Second, to prepare system diagrams, breaking the system down into 1dentifiable hardware components (250 in our initlal review). Third, to collect fallure mode data, based on experience with similar components. Fourth, to analyze the predicted avallability based on the current state of the art, and to compare this to the availability required in order to achieve our overall $90 \%$ factor. Fifth, from this analysis to identify the development effort required to close the gap between predicted and required avallability. Sixth, to review the design to measure the progress that is being made, and to adjust the goals for the systems and components. Finally, the process will be iterated periodically throughout the design and construction of the plant.

In closing, I would like to give you the current status of our three design efforts, A report describing a conceptual design of the $1000 \mathrm{Mwe}$ reference plant was evaluated last October by the Oak Ridge National Laboratory. Thls design is being up-dated and a revised report is nearing completion. The first 1000 Mwe plant might be ready for industry construction in the early $1970^{\prime} \mathbf{s}$ based on successful experience with the demonstration plant which is ta precede it. A conceptual design of a demonstration plant was completed in April and is currently being reviewed by the U.S. Atomic Energy Commis sion. We have recommended that the preliminary design, or Title I, for this plant be started in the very near future. The plant would then be available for operation in the early $1970^{\prime} \mathrm{s}$. The dual purpose plant effort has been assigned a secondary role, and is, therefore a longer range affair. We are currently doing size extrapolation studies, optimizing plant parameters, and studying the coupling of the reactor to the desalting equipment. Conceptual designs of dual purpose systems in the 3000 to $10,000 \mathrm{Mwt}$ size range will be completed in about a year. 